\title{
THE BASIC FOR AN ISLAMIC ORIENTED TERTIARY EDUCATION CURRICULUM IN PSYCHOLOGY
}

\author{
Wismaningsih Sudradjat \\ Kusdwiratri Setiono
}

\begin{abstract}
The goal of higher education in Psychology is to produce psychologists capable of conducting research and assisting people to solve their psychological problems. Psychology as a scientilic discipline originated from Western countries. The use of Western psychological concepts and theories has met with much criticism, because not ail fit in the islamic world.

Based on the above, if is proposed that the curriculum for tertiary education in Psychology should consist of 60\% Western Psychology (Contemporary Psychology) and $40 \%$ islanic adaptation. This strategy will give the opportunity for psychologists graduating from this program to keep up with the state of the art Contemporary Psychology, as well as getting the opportunity to do research to adapt psychological concepts and theories to the islamic world view. The rationale and elaboration of the proposed Indonesian Islamic Psychology Curriculum will be discussed as a moder.
\end{abstract}
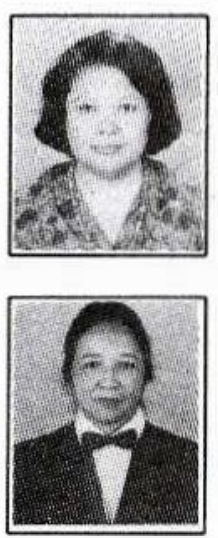

Dr. Wismaningsih sudradjat, adalah dosen pada Fakultas Psikologl UNPAD Bandung.

Prof. Dr. Kusdwiratri Seflono, adalah guru besar Fakultas Psikologi UNP,AD. Saat in menjabat Kelua Program Studi Psikologi Program Pascasar. jana Unpad. la juga akilf dalam berbagal pertenuan Ihriah nasional dan internasional.

\section{INTRODUCTION}

D sychology is a science that studies human behavior. With reference to its ety mology, the term psychology originates from the word psyche and logos = science; thus psychology is often defined as the science of man's psyche. However since the psyche as an object of the study of psychology is considered too abstract, psychology restricts itself to studying phenomena of the psyche, both overt as well as covert phenomena. Psychology was accepted as a modern science after Wilhelm Wundt established a psychology laboratory at Leipzig University in Germany, about a 
century ago. The contribution of psychoigy to people's Weliare has long been felt and the position of psychology in the scientific world has become stronger. This could be seen from various branches of applied psychology that have developed such as Clinical Psychology, Educational Psychology, Industrial and Organizational Psychology, Military Psychology, and Sport Psychology.

As a modem science that studies human behavior, contemporary psychology (also known as Western psychology, modern psychology, mainstream psychology, secular psychology, in this paper these terms have the same meaning) puts too much emphasis on observable behavior. Its method which tends to become more and more quantitative and mathematical has made Psychology gradually more distant from the spiritual side of man and seemingly soulless, as noted by Badri (1994): "a psychology without soul studying man without soul." In connection with this, before discussing the curriculum of islamic tertiary education in Psychology, it is necessary to first examine Psychology as a science with reference $b$ Islam. In Indoresia several books on the subject have been written by authorities in psychology, among others "islamic Psychology" (Djamaludin Ancok \& Fuad Nashori Suroso, 1994), "The Paradigma of Islamic Psychology" (Fuad Nashori Surdso ed., 1994). "The integration of Psychology and Islam" (Hanna Djumhana Bastaman, 1995). Translations of books also exist as for instance, "Islamic Psychology" written by Sayyid Mujtaba Musari Lari. The formulation of the meaning of Islamic Psychology in this paper has been derived from a study of these books.

At this moment, a number of Islamic oriented universities in Indonesia have opened faculties of psychology. Examples are the Islamic University of Bandung and the Muhammadiyah University of Surakarta. Moslem-religion kindergartens have also been established as well as elementary and secondary schools giving Moslemoriented educational programs. In addition to this, non-formal and informal education have increasingly become Moslem-oriented. Various magazines and newspapers are Moslem-oriented. Lectures and discussions on Islam are broadcasted daily on the radio and television. Besides these, prayer meelings are often held by housewives at home or in the mosques, at the office by employees, and at the mosques by youth groups. This means that more and more Indonesians, of whom $80 \%$ are Mosiem, are becoming knowledgeable in the Islamic religion. In anticipation of having to work in a setting consisting of people with an Islamic way of life, it is felt that an Islamic-oriented tertiary education in psychology is needed.

Tertiary education in Indonesia has to follow the guidelines established by the Directorate of Tertiary Education of the Department of Education. Thus, the curriculum of the faculty of psychology has to corespond to the Minister of Education's directive no. 0324/U/1994 on the National Curriculum sor Tertiary Education in Psychology. The objectives of tertiary education in Psychology, stated in the national curriculum are to produce graduates with a mastery in psychodiagnostics, counseling \& therapy, and research in psychology. At present, the content of the curriculum consists of theories and methods originating in Western countries. This national currculum has to be followed by all the facuities of psychology in Indonesia, both governmental as well as private. Fortunately, the national curriculum still gives the university freedom to determine $40 \%$ of the curriculum, In accordance with this, Islamicoriented faculties of psychology can include 
Islamic perspectives in their curricuhm.

This paper will propose the basis for the formulation of an Islamic-oriented tertary education curriculum that may be used by Faculties of Psychology in Islamic Universities to differentiate them form nonIslamic-oriented institutions. The discussion of the curriculum will be limited to eduacational objectives and the main points of the curriculum contents. The method and evaluation to be used in the curriculum wilf not be discussed in this paper.

\section{ISLAMIC PSYCHOLOGY}

Moslim intellectuals have thought about the Islamic perspectives of science since the end of the 14th century Hijrah. These views resulted from an increase in an awareness of the harmful imbalances caused by a separation between science and religion. Among other things, those can be seen by the development of more sophisticated technology but a further distancing from ethical and religious values. Psychology as a science studying man is especially vuinerable to such imbalances. It is necessary therefore to first examine psychology as a science and to conclude with a discussion of the Islamic perspective of man, because Islam holds its own views on mankind. In addition to which in Islam man's conscience, faith and knowledge are very important human characteristics.

Psychology as a scientific discipline fulfills the general criteria of science:

1. a formulation of the objectives of study.

2. basic concepts and clearly defined borders.

3. the opportunity for developing theories and principles.

4. methods and techniques for its application.

5. capable of being made known to the public, taught and studied (Fuad
Hassan, 1985).

The various views on the definition of Islamic Psychology could be classified into wo main approaches (Ancok \& Suroso, 1994). The first. states that what is known as Islamic Psychology is filtered modern psychology containing Islamic perspectives. Thus, the theories and concepts of the various school of modern psychology are examined. According to this first approach, it is our duty to eliminate those concepts that do not fit into Islam. The second approach, takes the position that Islamic Psychology is a science about man. Its conceptual framework is based on the formal foundations of Islam, the holy Qur'an and the Hadits and developed in accourdance with scientific criteria.

If we choose to take the second approach, it is necessary to first formulate the concept of man according to Islam, and develop further concepts of man based on this basic orientation. After this, scientific research using these concepts will be necessary. An Islamic oriented psychological approach could also serve for the development of human resources and in the solution of people's problems.

The steps $t$ be taken for the second approach are very basic, but need much time. In view of this, the first approach is recommended as a short-term strategy and the second approach for a long-term strategy.

Each school of thought, theory, system, method and technique in Psychology is generally founded and influenced by its particular "Model of Man" or its own way of defining the concept of man. At present various models of man exist in psychology as, for example, the Biological model and the Psychoanalytical, Behavioral, Humanistic, Existential and Interpersonal models (Bastaman, 1995). These models all have the same basic weakness of putting to 
much emphasis on one dimension of the concept of man, which is the physical dimension, the personal experience dimension or the socio-cultural dimension (Coleman, 1975).

Realizing this imbalance, experts in Psychology and Psychiatry have proposed a more comprehensive and eclectic-holistic model consisting of Organic-Biological, Psychological-Educational, and Socio-Cultural factors, which mutually influence each other. Although these comprehensive human factors are very important, they do not yet consider the most important dimension of man. This is the spiritual dimension which is a special characteristic of man and differentiate man from animal (Bastaman, 1955). There are a few psychologists and psychiatrists however, who have developed theories of man, which include the spiritual dimension. Viktor Frankl, the founder of Logotherapy for example, mentions three factors that descrihe man's existence. These factors are spirituality, freedom and responsihility (Frankl, 1973). However, Frankl himself emphasizes that the term spirituality has no religious connotation, but is just the menaingful experiencing as a result of man's capability of transcending himself and his environment. In the same way, Transpersonal Psychology which was founded by Humanistic Psychologists (among others the late Abraham Maslow) studies the spiritual side of man. This viewpoint is not too popular among modern psychologists who came to be too practi$\mathrm{cal}$ and more interested in ohservable phonomena. This condition causes a dilemma for Moslem psychologists, because on one hand is the realization that many models and schools of psychology are not Moslem oriented, while on the other hand Islamic Psychology itself has not been developed yet. For this reason, we can understand why Malik Badri wrote a hook titled "The Dilemma of Moslem Psychologists".

The Islamic concept of man may be understood from a study of the verses and hadits of the Holy Qur'an concerning ther prophet Adam who was created by Allah to be the ancestor of all mankind. This concept includes the following points (Bastaman, 1995):

1. Man's status is acknowledged to be very high. He functions as a leader on earth who is entrusted to execute God's will.

2. The Islamic perspective of man does not acknowledge the concept of original $\sin$. This means a person has to be responsible for himself. Each person can clean himself of his sins by asking God's forgiveness.

3. Man is a totality consisting of four dimensions: the physical-biological di mension, the mental-psychological dimension, the socio-cultural dimension, and the spiritual dimension.

4. The Islamic perspective on man acknowledges man's capability for thinking, understanding symbols, following intellectual activities and having a normative conscience.

5. Man has freedom of the will in striving for spiritual goodness or in striving for lower biological needs. It is understood that this freedom is not absolute. but is limited by his condition as a human being and he is still responsihle for his actions.

6. Besides his good points, man also has weaknesses which can cause him to go astray.

7. Man is not left to live his life without directlon from God. To man is given hope and the promise of being safe in this world and in the hereafter if he follows God's rules. 
The unique concept of man from an Islamic perspective forms the philosophical foundation for an Islamic orientated Psychology. It should be understood that the subject matter, theories, systems, methods and technique of modem psychology are still retained. Islamic psychology tries to complete the interpretation of the existing concepts.

Based on its philoshopical foundation of the concept of man, the formulation for defining Islamic Psychology is as proposed by Bastaman (1995: 10): "islamic Psychology is psychology based on the Moslem image of man. if studies the uniqueness and behavior of man as an expression of his interaction with himself, his environment, and his spirilualty with the ain of in creasing his mental health and quality of worship".

It should be remembered that Islamic Psychology still is open to suggestions for giving it special character. However, its scientific status as Psychology has to be fixed and agreed upon from the beginning. Islamic Psychology still has to fulfill the scientific standard of Psychology and science. Applied Islamic Psychology has to be prepared to handle all kinds of problems from all those people needing psychological help without differentiating between their religion and race. Limiting applied Islamic Psychology to certain problems only would cause a narrowing of viewpoint and not acknowledge the universality of Islam. It would also hinder the aim of creating a progressive Islamic oriented psychology which is hoped, to have a wider range than contemporary psychology. Man's experience, as the subject of study in contemporary psychology, is extended by also considering the spiritual experience of man (Bastaman, 1995 :12).

\section{THE OBJECTIVES OF TERTIARY EDU. CATION IN PSYCHOLOGY}

In accordance with the guidelines established in the national curriculum of Psychology, the objectives of tertiary education in Psychology may be grouped into general and specific aims.

The general abjectives are, to produce professionals qualified in the science of psychology who are capable of dealing with general psychological problems independently and effectively. The specific aims are to produce graduates capable of:

1. Understanding the basic principle of psychology and basic techniques for objective observations, in order to be able to interprete human behavior, individually as well as in group.

2. Conducting psychological research.

3. Selecting and using the right psychological instruments, and analyzing and interpreting the results of psychological services to individual as well as group.

4. Showing responsible sensitivity toward social, cultural, religious, political, and economic values, processes and problems affecting man's behavior, for the purpose of interpreting behavior in relations to the conditions in Indonesia.

5. Recognizing, experimenting and applying the ethical code of psychology which include scientific research and professional ethics.

6. Writhing professional and scientific report on research and psychological assessment.

The specilic objectives of Islamic oriented approach in Psychology are to produce professionals capable of:

1. Showing sensitivity and responsibility towards psychology. 
1. Showing sensitivity and responsibility towards psychology.

2. Understanding the Islamic concept of mental health.

3. Using Islamic orientations in dealing with psychological problems.

\section{THE MAIN POINTS FOR THE CONTENT OF PROPOSED CURRICULUM}

The content for the proposed curriculum for tertiary education in Psychology program. These are discussed in the following sections.

\section{Academic Program}

The academic program for a degree in psychology basically consists of general theories and concepts in psychology. A nomothetical approach is used (Wisnum brata ${ }_{1}$ 1995). The content for the general academic program will be discussed before the Isjamic oriented content.

\section{General Psychology and NonPsycho- logical courses}

General Psychology is necessary to give students an understanding of the definition of psychology, the area studied and its relation to other sciences, an understanding of the history of psychology, an understanding of various schools of psychology, an understanding of vaious theories and processes concerning perception, motivation, emotion, learning and thinking. For example, the psychological determinant of human behavior (Badri) are:

a The influence of early upbringing and child rearing practices on the psychological development of children and adolescent.

๖. The psychological influence of peer groups $\square$ The psychological influence of the school environment.

$\square$ The influence of psychological strees.

Non - Psychological courses necessary for understanding psychology consist of research methodology, statistics, philosophy, anthropology, sociology, physiology. neurology and biology.

\section{Islamic Oriented General Psychology and Non-Psychological Courses.}

The content for General Psychology should be supplemented with content describing their Islamic persepctives. For example, the psychological determinants of human behavior from Islamic perspectives (Badri) are:

$\exists$ The benefit of Islamic tarbia.

$\square$ The benefit of loving Muslim parents on the severity and happiness of the Muslim child and adolescent.

a The influence of application of Islamic teachings on child and adolescent rearing practices in developing healthy and happy Muslim individuals.

- The benefits of prayer and zikir in combating psychological stress and emotional stress.

Concerning research methodology, as with other sciences, research in Psychology is based on the principles of the scientific method such as observation and description, systematic analysis and prediction. These methods and principles are also used in Islamic Psychology. However, in Isiamic Psychology, qualita tive methods are as important as quatitative methods. Up till now the latter has received more attention in the curriculum, with the exception of Phenomenology.

\section{The Subdivisions of Psychology}


¿ Basic Psychology, which consists of the following subdisciplines: Developmental Psychology, Personality and Social Psychology.

$\checkmark$ Applied Psychology, which consists of Clinical Psychology, Educational Psychology, and Industrial and Organizational Psychology.

- Psychological techniques, which consists of Psychodiagnostics, Counseling and Psychotherapy.

\section{Islamic Oriented Subdivision of Psy- chology}

The content for basic, applied and techniques subdivisions of Psychology should be supplemented with content describing their Islamic perspectives. For example:

$\checkmark$ Social Psychology from Islamic perspectives is the leaching of silat alahim and its influence on the economic and emotional outreach and cohesion in Muslem societies (Badri).

- The teaching of psychodiagnostics, counseling and psychotherapy should be supplemented with discussion about the spiritual dimension of man and mental health according to Islam.

\section{The Professlonal Program in Psycho- $\log y$}

The main purpose of the professional program is to give practice and skills in applying all the theories and concepts taught in the academic program. A more ideographic approach is used (Wisnubrata, 1995), based on concrete phenomena and unique individual characteristics. The content for the practical training in the professional program will be discussed before the Islamic oniented content.

\section{Practical Training in Contemporary Mainstrean Psychology.}

Practical training is given in the departments of Clinical, Social, Educational, and industrial Psychology. The student is expected to become competent in the skills of psychological assessment, counseling and research in clinical, social, educational and industrial setting.

\section{Islamic-Oriented Practical Training.}

One of the purposes of psychology servises is to provide help in promoting mental health. The concept of a mentally healthy person is a person free of psychological symptoms, capable of self -adjustment and adjustment to the environment, and capable of self development. The Islamic perspective of mental health includes similar criteria founded on religious faith and devotion for the purpose of leading a meaningful and happy life in this world and a happy life hereafter. The spiritual dimension of man is considered a supporting factor in attaining mental health. This psychospiritual perspective, which is very evident in the practice of Islamic oriented Psychology, has to start with promoting the rellgious faith and devotion of the students them selves first. 


\section{REFERENCES}

Ancok, D. \& Suroso, F.N. 1994. Psikologi Islami. Yogyąkarta: Pustaka Pelajar.

Badri, M.B. 1979. The Dilemma of Muslim Psychologist. London: M.H.W. London Publisher.

Badri, M.B. Report on the Teaching of Psychology in UBD.

Bastaman, H.D. 1995. Integrasi Psikologi dengan Islam. Yogyakarta: Pustaka Pelajar \& Yayasan Insan Kamil.

Coleman, J.C. 1975. Abnomal Psychology and Modern Life. D.B. Taraporevala sons \& Co Private Ltd.
Hassan, F. 1985. "Ps ikologi \& Gejala Paranormal". Majalah Psikologi ANDA, No. 105, Jakarta.

Lari, S.M.M. 1990. Psikologi Islam (translation of Youth and Morah. Jakarta: Pustaka Hidayah.

Suroso, F.N. (Ed). 1994. Membangun Paradigma Psikologi Islami. Yogyakarta: Sinross.

Wisnubrata, H. 1995. Arah dan Pengembangan Pendidikan Tinggi Psikologi of Indonesia. Jakarta: Konsorsium Psikologi, Depdikbud. 